\title{
CENTRALIZACJA DECYZJI I DZIAŁAŃ W UNIWERSYTECKICH MODELACH KSZTAŁCENIA USTAWICZNEGO
}

\section{CENTRALIZATION OF DECISIONS AND ACTIVITIES IN UNIVERSITY LIFELONG LEARNING MODELS}

Katedra Strategii i Metod Zarządzania, Uniwersytet Ekonomiczny we Wrocławiu ul. Komandorska 118/120, 53-345 Wrocław, e-mail: janusz.lichtarski@ue.wroc.pl *Katedra Rachunkowości, Controllingu, Informatyki i Metod Ilościowych, Uniwersytet Ekonomiczny we Wrocławiu, ul. Komandorska 118/120, 53-345 Wrocław, e-mail: krzysztof.nowosielski@ue.wroc.pl

\begin{abstract}
Summary. Due to dynamic technological, social and economic changes the idea of lifelong learning (LLL) is becoming more and more popular. At the same time we can observe increasing role of universities in various forms of continuous education. Although lifelong learning can be widely understood, from university perspective it can be narrowed to postgraduate studies. As the opposite models of LLL organization in public universities (centralized vs decentralized) are too general, authors look for more detailed view. The purpose of the paper is to present analytical perspective of the postgraduate studies organization model in public universities. Key decisions and activities areas, as well as main participants were identified on the basis on multi case study - deepened comparative analysis of three public universities.
\end{abstract}

Słowa kluczowe: kształcenie ustawiczne, szkolnictwo wyższe, przedsiębiorczy uniwersytet, model scentralizowany, model rozproszony.

Key words: lifelong learning, higher education, entrepreneurial university, centralized model, dispersed model.

\section{WSTĘP}

Postęp techniczny i rozwój technologii teleinformatycznych ICT (Information and Communication Technologies), globalizacja gospodarki światowej, zmiany społeczno-ekonomiczne i zmiany zachodzące na rynku pracy stanowią wyzwanie dla obecnych i przyszłych pracowników i w zasadniczy sposób zmieniają ich potrzeby i podejście do edukacji i samorozwoju. W tym kontekście wydaje się, że tradycyjny model zdobywania kompetencji i potwierdzającego ich posiadanie wykształcenia jeszcze przed wejściem na rynek pracy wyczerpuje swój potencjał'. Koniecznością staje się uczenie się przez całe życie, w różnych formach i miejscach, mające na celu ciągły rozwój zawodowy, zdobywanie nowych kompetencji i aktualizację już posiadanych (Field 2006).

Obserwując strukturę oferty usług edukacyjnych, można zauważyć, że rośnie znaczenie kształcenia ustawicznego, którego istotą jest zdobywanie różnych umiejętności, mających znaczenie dla funkcjonowania jednostki przez jej całe życie i we wszystkich jego obszarach.

\footnotetext{
${ }^{1}$ Za tradycyjny uważa się podział życia jednostki na fazy uczenia się i aktywności zawodowej.
} 
Rośnie jednocześnie rola uniwersytetów i szkół wyższych w realizacji kształcenia ustawicznego, co stanowi odpowiedź na procesy demograficzne (starzenie się społeczeństw) i wpisuje się w szeroko pojmowaną zmianę modelu i roli uniwersytetów (zob. np. Clark 2004; Sułkowski i Seliga 2016).

Celem artykułu jest przede wszystkim przybliżenie cech modeli organizacji procesu kształcenia ustawicznego na uczelniach, opisywanych w literaturze przedmiotu, a mianowicie modelu scentralizowanego i zdecentralizowanego. Następnie, na tej podstawie, autorzy podjęli próbę identyfikacji kluczowych obszarów oraz poziomów centralizacji decyzji i działań w procesie kształcenia ustawicznego na wybranych przykładach krajowych uczelni publicznych.

Prezentowane w literaturze modele są zdaniem autorów zbyt ogólne. Brakuje także danych empirycznych potwierdzających ich skuteczność. Zamiarem autorów jest opracowanie takiego podejścia, które pozwoliłoby na określenie natężenia centralizacji decyzji i działań w ramach kilku kluczowych obszarów, a nie dla całego modelu, następnie zaś poszukiwanie zależności między stosowanymi na uczelniach rozwiązaniami a uzyskiwanymi efektami w postaci np. liczby słuchaczy i uczestników, wielkości przychodów itd. Wykorzystanie obiektywnych miar pozwoliłoby na lepszą weryfikację stosowanych modeli organizacji kształcenia ustawicznego na uczelniach.

W części pierwszej artykułu scharakteryzowano metody oraz procedurę badania. Następnie omówiono zagadnienie kształcenia ustawicznego, jego modele i uwarunkowania, bazując na dotychczasowym dorobku w tym zakresie. W kolejnym rozdziale przedstawiono wyniki badań dotyczących identyfikacji kluczowych obszarów i poziomów centralizacji decyzji oraz działań w procesie kształcenia ustawicznego na przykładzie studiów podyplomowych. W podsumowaniu przedstawiono najważniejsze rezultaty badań oraz propozycje kierunków dalszych prac.

\section{METODA BADAWCZA}

Biorąc pod uwagę złożoność przyjętego celu pracy oraz aktualny stan wiedzy naukowej, zastosowano dwa podejścia do badań:

1) charakterystykę modeli organizacji oraz istoty zagadnienia centralizacji procesów decyzyjnych w obszarze kształcenia ustawicznego na uczelniach przeprowadzono na podstawie podejścia deskryptywnego z wykorzystaniem wtórnych źródeł wiedzy; przeanalizowano dostępne opracowania naukowe oraz wyniki badań innych autorów (nie tylko z obszaru nauk o zarządzaniu, ale również pedagogiki); wnioski płynące z tej części prac wyznaczyły ramy oraz ukierunkowały kolejne badania;

2) identyfikację kluczowych obszarów oraz poziomów centralizacji decyzji i działań w procesie kształcenia ustawicznego przeprowadzono w drodze badań jakościowych; z uwagi na niewielką liczbę dostępnych opracowań naukowych oraz badań prowadzonych w tym obszarze prace podjęte przez autorów miały charakter eksploracyjno-deskryptywny (por. Yin 1984); w tej sytuacji za najbardziej odpowiednią metodę badawczą uznano analizę przypadku (ang. case study). Trafność wyboru tej metody potwierdzają opracowania takich autorów, jak Benbasat i in. (1987), a także Yin (1984), według których analizy przypadku ma sens szczególnie wtedy, gdy:

- zjawisko jest badane w warunkach naturalnych (inaczej niż np. w przypadku eksperymentu naukowego); 
- badaniu podlega jeden obiekt lub kilka obiektów;

- badania są na etapie eksploracji obszaru wiedzy, tworzenia klasyfikacji, rozwoju hipotez;

- nie dokonuje się manipulacji obiektem badanym;

- nie można jednoznacznie wskazać zmiennych zależnych i niezależnych niezbędnych w badaniu ilościowym;

- obiekt jest badany kompleksowo, prace są skoncentrowane na obserwacji i analizie zjawisk, a nie na badaniu zależności występującymi między zmiennymi.

Identyfikacja kluczowych obszarów oraz poziomów centralizacji decyzji i działań w procesie kształcenia ustawicznego została przeprowadzona według następującej procedury (Yin 1984):

1) zdefiniowanie problemu,

2) zaprojektowanie badania,

3) gromadzenie danych,

4) analiza zgromadzonych danych i opracowanie wniosków.

Podstawowy problem badawczy można sformułować w postaci pytań:

- Jakie są poziomy podejmowania decyzji związanych z procesem kształcenia ustawicznego na uczelni i poziomy wykonania działań związanych z tymi decyzjami (poziomy centralizacji decyzji i działań)?

- W jakich obszarach lokują się decyzje i działania z nimi związane w procesie przygotowania i realizacji studiów podyplomowych?

Projekt badań sprowadza się do sporządzenia listy obiektów objętych badaniem, wyboru procesu kształcenia oraz dokumentów do analizy. Z uwagi na zróżnicowanie oraz liczebność podmiotów kwalifikujących się do badania, a także ze względu na różnorodność procesów kształcenia ustawicznego, realizowanych przez te podmioty, autorzy zdecydowali się na wprowadzenie celowych ograniczeń. Uwagę skoncentrowano na procesach kształcenia zorganizowanych w formie studiów podyplomowych (edukacja formalna), realizowanych na trzech krajowych publicznych uczelniach ekonomicznych. Wybór konkretnej formy kształcenia do badania został uwarunkowany ogólną dostępnością materiałów źródłowych, dominującym udziałem tej formy w ofercie kształcenia ustawicznego badanych uczelni, udziałem przychodów ze studiów podyplomowych w budżecie uczelni, a także zainteresowaniami i doświadczeniami autorów. W związku z tym, że celem naukowym była nie ocena rozwiązań przyjętych w badanych podmiotach, lecz uzyskanie szerszego spojrzenia na rozpatrywany problem, nazwy uczelni, z wyjątkiem macierzystej uczelni autorów, zostały zakodowane symbolami $U x$. W sumie przebadano dokumentację wewnętrzną 3 uczelni publicznych o profilu ekonomicznym, działających w różnych miastach kraju. Badane uczelnie są uznawane w różnych zestawieniach i rankingach za największe jednostki tego typu w Polsce.

Na liście dokumentów poddanych analizie umieszczono:

- Ustawę Prawo o szkolnictwie wyższym z dnia 27 lipca 2005 r. (dalej: Ustawa) jako dokument nadrzędny określający ramy organizacji studiów podyplomowych;

- regulaminy studiów podyplomowych zatwierdzone uchwałami stosownych organów kolegialnych badanych uczelni, zarządzenia rektorów oraz pisma okólne. Dokumenty zostały pobrane w listopadzie 2016 r. w formie elektronicznej ze stron internetowych badanych uczelni. 
Ponadto przeprowadzono wywiad nieustrukturyzowany z przedstawicielami badanych uczelni, zaangażowanymi w organizację różnych form kształcenia ustawicznego.

Analiza danych została przeprowadzona po zakończeniu gromadzenia danych. W związku z jakościowym charakterem badań oraz materiału badawczego przeprowadzone prace polegały przede wszystkim na:

- identyfikacji decyzji i działań podejmowanych w trakcie procesu organizowania i realizacji studiów podyplomowych,

- określeniu poziomu centralizacji zidentyfikowanych decyzji i działań,

- obszarowej klasyfikacji i opisie zidentyfikowanych decyzji i działań.

\section{KSZTAŁCENIE USTAWICZNE NA UCZELNIACH I MODELE JEGO REALIZACJI. PRZEGLĄD LITERATURY}

Mimo pewnych różnic w definiowaniu kształcenie ustawiczne przedstawiane jest w zbliżony sposób - jako ogół działań zorientowanych na ciągły rozwój jednostki, zdobywanie i aktualizację kompetencji w różnych obszarach i formach, podejmowanych świadomie i z własnej inicjatywy (por. Dave 1976; Kidd 1993; Półturzycki 1993; Symela 1997). W poszczególnych ujęciach zakres kształcenia ustawicznego jest oczywiście w różny sposób przedstawiany; w literaturze spotkać można wiele dyskursów, ale panuje zgodność co do podstawowych cech tego kształcenia, a mianowicie, że jest to proces ciągły, dotyczy osób w każdym wieku, a uczestnictwo w nim jednostek ma charakter dobrowolny i wynika z własnych wyborów.

W tej perspektywie kształcenie ustawiczne jawi się jako szeroki zbiór działań, obejmujących edukację na różnych jej szczeblach i w różnych formach, zarówno w systemach formalnych, jak i poza nimi jako tzw. edukacja nieformalna. W procesie kształcenia ustawicznego zadania są podzielone pomiędzy wiele podmiotów, w szczególności pomiędzy urzędy i instytucje publiczne, instytucje prywatne realizujące zadania w obszarze edukacji oraz instytucje prywatne, przy czym istotną rolę odgrywają uczelnie.

Z uwagi na cel opracowania i obiekt badań, tj. uczelnie, pojęcie kształcenia ustawicznego na potrzeby niniejszego artykułu zostało ograniczone do edukacji formalnej, a dokładniej do studiów podyplomowych realizowanych przez uczelnie. Jednocześnie autorzy artykułu mają świadomość, że w praktyce na uczelniach, poza studiami podyplomowymi, do działań związanych z szeroko rozumianym kształceniem ustawicznym należy zaliczyć między innymi: organizację szkoleń i kursów, tworzenie uniwersytetów trzeciego wieku, prowadzenie uniwersytetów otwartych, rozwój forów edukacyjnych, organizację wykładów i seminariów otwartych, tworzenie możliwości formalnego potwierdzania kompetencji zdobytych poza formalnym systemem kształcenia, budowanie wokół ośrodków akademickich społeczności praktyków czy rozwijanie inkubatorów przedsiębiorczości. Wszystkie te działania są składnikami szeroko pojmowanego kształcenia ustawicznego. Jednak $z$ uwagi na skalę realizowanych działań ich wpływ na sytuację ekonomiczną uczelni i doświadczenia zawodowe autorów w niniejszym artykule skoncentrowano się na analizie modeli organizacji studiów podyplomowych i szkoleń.

Warto podkreślić, że do niedawna rola uczelni w kształceniu ustawicznym w Polsce była niedostrzegana i niedoceniana, czego przyczyn można szukać m.in. w braku odpowiednich 
regulacji prawnych uwzględniających rolę uczelni w rozwoju całożyciowego uczenia się, a także w tradycjach uniwersyteckich i uwarunkowaniach społeczno-kulturowych. Przez lata uczelnie były bowiem budowane na wzór modelu humboldtowskiego i pełniły funkcję „świątyń wiedzy", rozwijających naukę w wymiarze badań podstawowych, dostępną tylko dla wybranej grupy. Dopiero niedawne zmiany, które zaszły w otoczeniu uczelni, zrodziły potrzebę zmian w kierunku uniwersytetu przedsiębiorczego (Clark 2004; Sułkowski i Seliga 2016).

Uniwersytety stopniowo otwierają się więc na kształcenie ustawiczne, rozszerzając i dostosowując ofertę edukacyjną do coraz szerszej grupy odbiorców. Katalizatorem tych zmian są zarówno rosnące potrzeby społeczeństwa, jak również działania na poziomie Unii Europejskiej (wystarczy wskazać m.in. deklarację bolońską). Jeśli zmiany te zostaną w pełni przyjęte przez uczelnie, to w niedalekiej przyszłości mogą one odgrywać główną rolę w rozwoju kształcenia ustawicznego i realizacji idei społeczeństwa opartego na wiedzy. Podkreślono to m.in. w raporcie Delorsa (1998), przedstawiającym kierunki rozwoju edukacji w XXI wieku. Zawarte w nim hipotezy wskazują na rolę uniwersytetów wykraczającą poza realizację idei powszechnego kształcenia. Mają one również odnawiać system kształcenia oraz wypracowywać i wdrażać innowacje edukacyjne w tym obszarze. Istotnym dla rozwoju kształcenia ustawicznego kierunkiem zmian jest zatem zmiana sposobu pojmowania roli uczelni w realizacji i rozwoju tej idei.

Jednym z kluczowych czynników wpływających na jakość i możliwości rozwoju kształcenia ustawicznego na uczelniach jest stosowany model organizacyjny tej formy edukacyjnej. W literaturze najczęściej charakteryzowane są dwa przeciwstawne modele - scentralizowany i rozproszony, przy czym przeprowadzone dekadę temu badania wskazują, że na większości polskich uczelni publicznych był realizowany model rozproszony (Wiśniewski 2006). Jak podkreśla przywołany autor, dominacja modelu zdecentralizowanego wynika z historycznych uwarunkowań rozwoju uczelni publicznych w naszym kraju, które przez wiele dekad nie były zmuszone do samodzielnego poszukiwania źródeł finansowania działalności, jak również z dużej autonomii jednostek (wydziałów) wynikającej bezpośrednio z regulacji prawnych (ustaw).

Główne zalety modelu rozproszonego (zdecentralizowanego) związane są z dużą swobodą w realizacji działań z obszaru kształcenia ustawicznego, w kwestiach merytorycznych, organizacyjnych, administracyjnych i finansowych. Wysoki poziom autonomii pozwala na tworzenie rozwiązań dostosowanych do potrzeb i specyfiki jednostki oraz sprzyja pobudzaniu inicjatywy oddolnej i większemu zaangażowaniu pracowników. Wśród słabych stron modelu rozproszonego możemy, między innymi, wyróżnić brak jednolitych procedur i standardów obsługi w skali uczelni, co akcentowane jest m.in. przez instytucje kontrolne, np. NIK czy PKA, a także brak spójności działań promujących ofertę kształcenia ustawicznego czy zagrożenie występowaniem konkurencji wewnętrznej i wzajemną „kanibalizacją” kierunków studiów.

W wielu ośrodkach zagranicznych, a także na wybranych uczelniach krajowych (głównie niepublicznych) kształcenie ustawiczne jest realizowane w modelu scentralizowanym, czyli przez wyodrębnione w tym celu ośrodki w strukturze uczelni, działające przeważnie niezależnie od wydziałów. Ośrodki te wykorzystują niekiedy odrębną bazę techniczną i dysponują ograniczoną samodzielnością finansową. Wykorzystują przy tym kadrę dydaktyczną macierzystej uczelni i specjalistów z jej bliskiego otoczenia. 
Wiśniewski (2006), porównując modele organizacji kształcenia ustawicznego na uczelniach, wskazuje na przewagę modelu scentralizowanego między innymi w zakresie: lepszych możliwości strategicznego planowania działalności, lepszej alokacji finansów, większych możliwości ubiegania się o fundusze unijne, bardziej racjonalnej gospodarki środkami technicznymi, większych możliwości badania rynku edukacyjnego, systematycznej analizy jakości kształcenia, większej możliwości działań motywacyjnych w przygotowywaniu programów edukacyjnych na potrzeby regionu. Wyższość modelu rozproszonego wyraża się natomiast w liczebności zespołu powołanego do realizacji kształcenia ustawicznego (brak odrębnych struktur, realizacja zadań przez dziekanaty) i w lepszym kontakcie z uczącymi się.

Wydaje się, że niektóre wskazane przewagi modelu scentralizowanego i rozproszonego, przedstawione przez Wiśniewskiego (2006), są dyskusyjne z perspektywy obecnego rozwoju nauk o zarządzaniu oraz możliwości zastosowania nowoczesnych rozwiązań technicznych. Przykładowo, rozwiązania informatyczne typu cloud pozwalają na ograniczenie kosztów administracyjnych (transakcyjnych) do tego poziomu, w którym nie różnicują one już różnych form organizacyjnego współdziałania, a nowoczesne technologie (np. e-dziekanat) w sposób radykalny zmieniają sposób kontaktu z kandydatami i słuchaczami. Przy obecnym stanie rozwoju możliwych do zastosowania narzędzi wspomagających komunikację i zarządzanie warto ponownie przeanalizować mocne strony i słabości poszczególnych modeli.

Należy również zauważyć, że w praktyce, m.in. ze względu na uwarunkowania prawne (w myśl Ustawy jednostką odpowiedzialną za merytoryczną organizację studiów podyplomowych jest wydział), wdrożenie modelu scentralizowanego w jego czystej postaci nie jest możliwe. Podobnie zresztą jest z modelem rozproszonym - ponieważ wydziały nie posiadają pełnej samodzielności finansowej, wymagany jest pewien poziom ujednolicenia procedur, zasad, narzędzi i dokumentacji.

W końcu należy zauważyć, że w krajowej literaturze brakuje opisu badań empirycznych, dotyczących związków między stosowanym przez uczelnie modelem organizacji kształcenia ustawicznego a skutecznością działań w tym obszarze. Oceny cech poszczególnych modeli są najczęściej subiektywne i bazują na zróżnicowanych doświadczeniach autorów, co uniemożliwia ich porównanie.

Sygnalizowane wątpliwości skłoniły autorów do odejścia od ogólnego dychotomicznego podziału na model scentralizowany i zdecentralizowany oraz do podjęcia próby bardziej analitycznego spojrzenia na model organizacji kształcenia ustawicznego na uczelniach. W proponowanym podejściu poziom centralizacji decyzji i działań jest rozpatrywany oddzielnie dla kluczowych obszarów decyzji i działań dotyczących przygotowania oraz realizacji studiów podyplomowych, a nie ogólnie dla całego systemu zarządzania kształceniem ustawicznym.

\section{MODEL ORGANIZACJI KSZTAŁCENIA USTAWICZNEGO UCZELNI. SPOJRZENIE ANALITYCZNE}

W związku z tym, że proces przygotowania i realizacji studiów podyplomowych składa się z wielu działań oraz decyzji, w których mogą uczestniczyć różne jednostki i podmioty wewnętrzne uczelni, dla lepszego zrozumienia istoty zagadnienia przygotowano przykładowy schemat takiego procesu (ryc. 1). Schemat obejmuje proces przygotowania i uruchomienia 
studiów podyplomowych na uczelni macierzystej autorów, tzn. na Uniwersytecie Ekonomicznym we Wrocławiu (U1). W schemacie uwzględniono rodzaje decyzji i działań oraz poziom struktury Uczelni, na którym te decyzje są podejmowane, a działania realizowane.

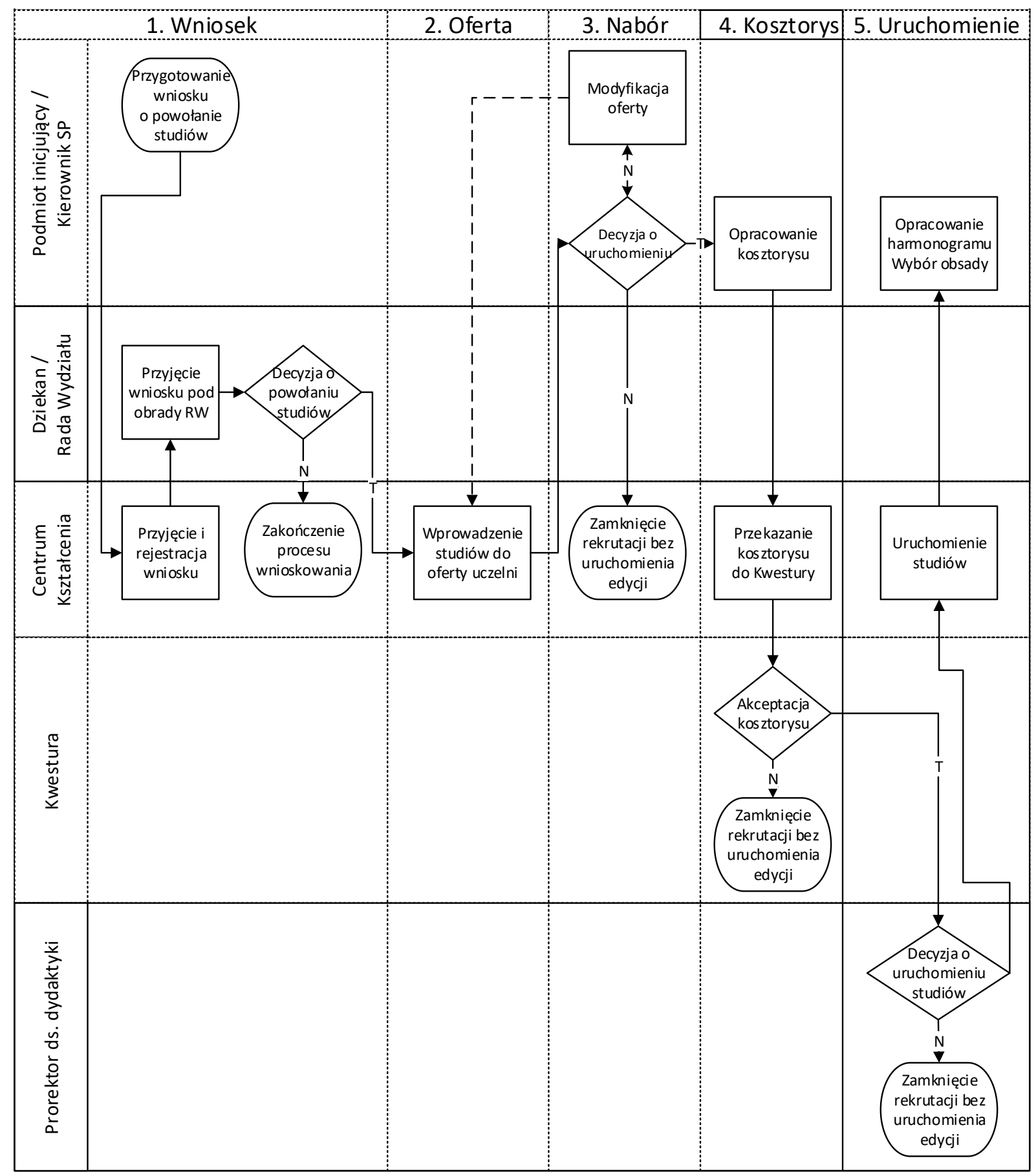

Ryc. 1. Przykład procesu organizowania studiów podyplomowych (fazy przedrealizacyjnej) w jednostce U1 Źródło: opracowano na podstawie regulaminu organizacyjnego Uniwersytetu Ekonomicznego we Wrocławiu (U1).

Jak widać na ryc. 1 , w procesie uczestniczą władze rektorskie, dziekańskie, pracownicy podstawowych jednostek organizacyjnych oraz jednostek organizacyjnych o charakterze wspomagającym (Centrum Kształcenia Ustawicznego). Ich rola polega na podejmowaniu 
decyzji i realizacji zadań, które warunkują działania prowadzące do uruchomienia kolejnych edycji studiów podyplomowych. Biorąc pod uwagę rozpiętość szczebli decyzyjnych, zaprezentowany obraz można uznać za typowy dla badanych uczelni. Na najniższym poziomie struktury decyzyjnej znajdują się pracownicy naukowo-dydaktyczni uczelni, pełniący funkcje kierowników studiów podyplomowych, a na poziomie najwyższym - jednoosobowe organy władz rektorskich.

Z punktu widzenia regulacji ustawowych istnieją duże możliwości wyboru modelu organizacji studiów podyplomowych oraz szczegółowych rozwiązań odnośnie do poziomu centralizacji decyzji i działań w zakresie tworzenia oferty oraz powoływania kierunków studiów podyplomowych w ramach uczelni publicznej ${ }^{2}$. Ustawa określa m.in.:

1) wymagania wobec kandydata na studia (art. 2, ust. 1, pkt 11 Ustawy);

2) kwalifikacje podyplomowe (art. 2, ust. 1, pkt 18 oraz art. 8a, ust. 2 Ustawy);

3) jednostki mające prawo prowadzenia studiów podyplomowych (art. 6, ust. 1, pkt 5 Ustawy) oraz wydawania świadectw ukończenia studiów podyplomowych (art. 6, ust. 1, pkt 6 Ustawy);

4) minimalny czas trwania studiów podyplomowych określony liczbą semestrów oraz minimalną liczbę punktów ECTS (art. 8a, ust. 1 Ustawy);

5) rolę rady podstawowej jednostki organizacyjnej w uchwalaniu programu studiów (art. 68, ust. 1, pkt 2 Ustawy);

6) prawo podstawowej jednostki organizacyjnej uczelni do potwierdzania efektów uczenia się na danym kierunku (art. 170e, ust. 1 Ustawy);

7) rolę Senatu uczelni (lub innego organu kolegialnego) w organizacji potwierdzania efektów uczenia się na kierunku (art. 170f Ustawy).

Badane uczelnie wprowadziły zróżnicowane rozwiązania (zgodne z Ustawą), jeśli chodzi o model organizacji studiów podyplomowych. Zróżnicowanie dotyczy zarówno przebiegu procesu przygotowania studiów, ich realizacji, jak i jednostek zaangażowanych w procesy decyzyjne i działania z nimi związane. Oznacza to, że również poziom centralizacji badanych procesów jest różny.

W toku prac analitycznych zidentyfikowano 7 typowych obiektów struktury organizacyjnej uczelni, które są zaangażowane w procesy decyzyjne lub realizują określone działania na różnych etapach procesu organizowania i realizacji studiów podyplomowych. Obiekty te zostały przypisane do 5 poziomów struktury zarządzania oraz określone ze względu na rolę, jaką odgrywają w organizacji. Im wyższa jest pozycja obiektu na liście, tym wyższy jest poziom centralizacji decyzji i działań, które są przypisane do tego obiektu w ramach danego procesu. Lista zidentyfikowanych obiektów wraz z przypisaniem do określonego poziomu oraz krótką charakterystyką została przedstawiona w tab. 1.

Zidentyfikowano także kluczowe obszary decyzji i działań, które występują w procesie organizowania i realizacji studiów podyplomowych. W związku z zastosowaną metodą badawczą, tzn. analizą przypadków, lista nie może być uznana za ostateczną. Rozszerzenie badań na inne podmioty może skutkować potrzebą modyfikacji listy poprzez dodanie nowych obszarów decyzji i działań lub modyfikację istniejących. W tabeli 2 przedstawiono listę obszarów wraz z przykładowymi decyzjami i działaniami wstępnie przypisanymi do poziomów zaprezentowanych w tab. 1.

\footnotetext{
2 Uwagę skoncentrowano na tej części zapisów Ustawy, która odnoszą się do badanych jednostek, tj. uczelni publicznych o profilu ekonomicznym. Nie badano tych elementów Ustawy, które dotyczą takich jednostek, jak Centrum Medyczne Kształcenia Podyplomowego z siedzibą w Warszawie, czy instytutów naukowych Polskiej Akademii Nauk.
} 
Tabela 1. Lista zidentyfikowanych obiektów struktury uczelni wg poziomu w strukturze uczelni

\begin{tabular}{|l|l|l|c|}
\hline Poziom & \multicolumn{1}{|c|}{ Nazwa obiektu } & \multicolumn{1}{c|}{ Rodzaj obiektu wg UoSW } & Rola w procesie \\
\hline P1 & rektor & organ jednoosobowy & decyzje \\
\hline P2 & prorektorzy & zastępca rektora & decyzje \\
\hline P3 & kwestor & kwestor & decyzje \\
\hline P4 & centrum kształcenia & administracja uczelni & decyzje / działania \\
\hline P5 & dziekan & organ jednoosobowy & decyzje / działania \\
\hline P6 & rada wydziału & organ kolegialny & decyzje / działania \\
\hline P7 & kierownik jednostki organizacyjnej & jednostka organizacyjna uczelni & decyzje / działania \\
\hline P8 & kierownik studiów podyplomowych & nauczyciel akademicki & decyzje / działania \\
\hline
\end{tabular}

Źródło: opracowano na podstawie dokumentów wewnętrznych badanych uczelni.

Z danych zgromadzonych w tab. 2 wynika, że w badanych jednostkach decyzje i działania dotyczące organizacji oraz uruchomienia studiów są podejmowane na różnych poziomach struktury organizacyjnej uczelni. Senat każdej badanej uczelni, jako organ kolegialny zobowiązany ustawowo do uchwalania regulaminu studiów, rozdysponował i przydzielił do poszczególnych stanowisk (obiektów) wiele kompetencji decyzyjnych dotyczących organizacji kształcenia na studiach podyplomowych. Szczegółowość wprowadzonych regulacji jest bardzo różna, o czym świadczy także różna objętość badanych regulaminów studiów (w jednym przypadku to 6 stron, a w innym 18 stron tekstu).

Zjawiskiem charakterystycznym dla badanych procesów decyzyjnych jest ich wieloinstancyjność. Przykładowo, kosztorys przygotowany przez kierownika studiów w niektórych przypadkach przechodzi przez ścieżkę opiniowania, obejmującą radę wydziału, dziekana, kwestora i rektora uczelni. W takim przypadku trudno jest jednoznacznie rozstrzygnąć, bazując jedynie na regulacjach, na którym etapie w rzeczywistości podejmowana jest decyzja, a gdzie ma miejsce podpisanie przedłożonego dokumentu. Różna jest także szczegółowość tych decyzji. W niektórych przypadkach kosztorys jest akceptowany jako całość, w innych przypadkach ma miejsce podział decyzji dotyczących poszczególnych składników kosztorysu na różne poziomy struktury, na przykład decyzje dotyczące części przychodowej kosztorysu, w tym ustalania wielkości opłat za studia i warunków płatności, czy części kosztowej, w tym ustalania stawek wynagrodzeń i sposobu wyliczania poszczególnych pozycji dotyczących zużycia innych zasobów.

Zróżnicowanie rozwiązań szczegółowych w regulacjach wewnętrznych jest działaniem zgodnym z zapisami Ustawy, niemniej jednak w istotny sposób wpływa na możliwości jasnego określenia poziomu centralizacji działań i decyzji. Chcąc całościowo ocenić każde badane rozwiązanie (przypadek), bez wnikania w szczegóły procesów decyzyjnych, należy stwierdzić, że żadne rozwiązanie nie zbliżyło się do modeli opisanych w poprzednim rozdziale, czyli do modelu scentralizowanego lub zdecentralizowanego. W tym kontekście olbrzymim wyzwaniem wydaje się stworzenie podejścia pozwalającego na odpowiedni pomiar natężenia centralizacji decyzji i działań w procesie organizowania i realizacji studiów podyplomowych. 
Tabela 2. Zestawienie decyzji i działań podejmowanych w ramach organizacji procesu studiów podyplomowych na badanych uczelniach

\begin{tabular}{|c|c|c|c|c|c|}
\hline \multirow{2}{*}{$\begin{array}{l}\text { Nazwa } \\
\text { obszaru }\end{array}$} & \multirow{2}{*}{ Składnik obszaru } & \multirow{2}{*}{$\begin{array}{c}\text { Rodzaj } \\
\text { zdarzenia* }^{*}\end{array}$} & \multicolumn{3}{|c|}{ Podmiot podejmujący decyzje / realizujący działanie (poziom struktury) } \\
\hline & & & U1 (UE we Wrocławiu) & $\mathrm{U} 2$ & $\mathrm{U} 3$ \\
\hline \multirow[t]{2}{*}{ Organizacja } & \multirow{2}{*}{$\begin{array}{l}\text { wniosek } \\
\text { o uruchomienie } \\
\text { studiów }\end{array}$} & 1 & $\begin{array}{l}\text { (P8) pracownik ze stopniem co najmniej } \\
\text { doktora }\end{array}$ & $\begin{array}{l}\text { (P7) kierownik jednostki organizacyjnej, np. } \\
\text { katedry } \\
\text { (P4) wymagana opinia Centrum Kształcenia } \\
\text { dla I edycji }\end{array}$ & $\begin{array}{l}\text { (P7) kierownik jednostki organizacyjnej, np. } \\
\text { katedry }\end{array}$ \\
\hline & & 2 & (P5) prorektor ds. dydaktyki zatwierdza & (P1) rektor zatwierdza & $\begin{array}{l}\text { (P6) Rada Wydziału wyraża zgodę na utwo- } \\
\text { rzenie studiów przez Dziekana } \\
\text { (P1) rektor ogłasza }\end{array}$ \\
\hline \multirow{2}{*}{ Organizacja } & \multirow{2}{*}{$\begin{array}{l}\text { Czas trwania } \\
\text { studiów }\end{array}$} & 1 & $\begin{array}{l}\text { (P8) wnioskodawca, pracownik ze stopniem } \\
\text { co najmniej doktora określa }\end{array}$ & $\begin{array}{l}\text { (P7) kierownik jednostki organizacyjnej przy- } \\
\text { gotowuje }\end{array}$ & $\begin{array}{l}\text { (P7)kierownik jednostki organizacyjnej, np. } \\
\text { katedry }\end{array}$ \\
\hline & & 2 & $\begin{array}{l}\text { (P6) Rada Wydziału opiniuje } \\
\text { (P2) prorektor zatwierdza }\end{array}$ & (P1) rektor zatwierdza & (P6) Rada Wydziału zatwierdza \\
\hline \multirow{2}{*}{ Organizacja } & \multirow{2}{*}{$\begin{array}{l}\text { warunki } \\
\text { ukończenia } \\
\text { studiów }\end{array}$} & 1 & $\begin{array}{l}\text { (P8) wnioskodawca, pracownik ze stopniem } \\
\text { co najmniej doktora określa }\end{array}$ & $\begin{array}{l}\text { (P7) kierownik jednostki organizacyjnej przy- } \\
\text { gotowuje }\end{array}$ & $\begin{array}{l}\text { ograniczone regulaminem obrony pracy } \\
\text { (P6) Rada Wydziału może zmienić }\end{array}$ \\
\hline & & 2 & $\begin{array}{l}\text { (P6) Rada Wydziału opiniuje } \\
\text { (P2) prorektor zatwierdza }\end{array}$ & (P1) rektor zatwierdza & - \\
\hline \multirow{2}{*}{$\begin{array}{l}\text { Program / } \\
\text { obsada }\end{array}$} & \multirow{2}{*}{$\begin{array}{l}\text { program } \\
\text { i efekty } \\
\text { kształcenia }\end{array}$} & 1 & $\begin{array}{l}\text { (P1) wnioskodawca, pracownik ze stopniem } \\
\text { co najmniej doktora przygotowuje }\end{array}$ & $\begin{array}{l}\text { (P1) kierownik studiów przygotowuje projekt } \\
\text { programu }\end{array}$ & $\begin{array}{l}\text { (P7) kierownik jednostki organizacyjnej, np. } \\
\text { katedry }\end{array}$ \\
\hline & & 2 & $\begin{array}{l}\text { (P6) Rada Wydziału opiniuje } \\
\text { (P2) prorektor zatwierdza }\end{array}$ & (P6) Rada Wydziału zatwierdza & (P6) Rada Wydziału zatwierdza \\
\hline \multirow{2}{*}{$\begin{array}{l}\text { Program / } \\
\text { obsada }\end{array}$} & \multirow{2}{*}{ obsada zajęć } & 1 & $\begin{array}{l}\text { (P8) kierownik studiów wskazuje (wytyczne } \\
\text { ogólne w regulaminie) }\end{array}$ & $\begin{array}{l}\text { (P8) kierownik studiów proponuje i zapew- } \\
\text { nia }\end{array}$ & (P1) kierownik studiów proponuje \\
\hline & & 2 & $\begin{array}{l}\text { brak, ogólne wytyczne w regulaminie stu- } \\
\text { diów }\end{array}$ & $\begin{array}{l}\text { (P6) Rada Wydziału zatwierdza na warun- } \\
\text { kach regulaminu }\end{array}$ & (P5) dziekan zatwierdza \\
\hline \multirow{2}{*}{ Finanse } & \multirow{2}{*}{$\begin{array}{l}\text { wysokość opłaty } \\
\text { za studia }\end{array}$} & 1 & $\begin{array}{l}\text { (P8) wnioskodawca, pracownik ze stopniem } \\
\text { co najmniej doktora określa }\end{array}$ & (P1) rektor ustala & (P1) kierownik studiów przygotowuje \\
\hline & & 2 & $\begin{array}{l}\text { (P6) Rada Wydziału opiniuje } \\
\text { (P2) prorektor zatwierdza }\end{array}$ & - & (P1) rektor zatwierdza \\
\hline \multirow[t]{2}{*}{ Finanse } & \multirow[t]{2}{*}{ kosztorys } & 1 & (P1) kierownik studiów przygotowuje & (P8) kierownik studiów przygotowuje & $\begin{array}{l}\text { (P1) kierownik studiów przygotowuje } \\
\text { (P3) kwestor sprawdza pod względem ra- } \\
\text { chunkowym }\end{array}$ \\
\hline & & 2 & $\begin{array}{l}\text { (P3) kwestor akceptuje } \\
\text { (P2) prorektor zatwierdza }\end{array}$ & (P1) rektor akceptuje & $\begin{array}{l}\text { (P5) dziekan akceptuje } \\
\text { (P1) rektor zatwierdza }\end{array}$ \\
\hline \multirow{2}{*}{ Finanse } & \multirow{2}{*}{$\begin{array}{l}\text { warunki płatności } \\
\text { (terminy / raty) }\end{array}$} & 1 & (P8) kierownik studiów określa & (P6) Rada Wydziału określa warianty & $\begin{array}{l}\text { (P8) kierownik studiów określa terminy płat- } \\
\text { ności }\end{array}$ \\
\hline & & 2 & - & (P1) rektor określa w akcie o uruchomieniu & $\begin{array}{l}\text { (P1) rektor decyduje o rozłożeniu na raty } \\
\text { w uzasadnionych przypadkach }\end{array}$ \\
\hline \multirow{2}{*}{ Administracja } & \multirow{2}{*}{ terminy zajęć } & 1 & (P1) kierownik studiów przygotowuje & (P1) kierownik studiów przygotowuje & (P1) kierownik studiów przygotowuje \\
\hline & & 2 & - & - & - \\
\hline \multirow[t]{2}{*}{ Administracja } & \multirow{2}{*}{$\begin{array}{l}\text { obsługa } \\
\text { administracyjna }\end{array}$} & 1 & $\begin{array}{l}\text { (P4) Centrum Kształcenia Ustawicznego re- } \\
\text { alizuje }\end{array}$ & (P8) kierownik studiów zapewnia & brak danych \\
\hline & & 2 & - & (P5) dziekan akceptuje & - \\
\hline \multirow[b]{2}{*}{ Administracja } & \multirow{2}{*}{$\begin{array}{l}\text { skreślenie z listy } \\
\text { słuchacza }\end{array}$} & 1 & (P1) kierownik studiów wnioskuje & (P1) kierownik studiów wnioskuje & - \\
\hline & & 2 & (P5) dziekan decyduje & (P5) dziekan decyduje & $\begin{array}{l}\text { (P1) kierownik studiów decyduje na warun- } \\
\text { kach regulaminu }\end{array}$ \\
\hline
\end{tabular}

* 1 - działania - kto określa / przygotowuje, 2 - decyzja - kto opiniuje / akceptuje / zatwierdza / ogłasza decyzję.
Żródło: opracowano na podstawie wyników badań własnych. 


\section{DYSKUSJA I WNIOSKI}

Zaproponowane podejście pozwala na bardziej analityczne spojrzenie na stosowany model organizacji kształcenia ustawicznego niż na modele prezentowane w literaturze. Wyróżnienie 4 kluczowych obszarów decyzji i działań, takich jak organizacja, program i obsada, finanse oraz administracja, pozwala na dokonanie pogłębionej diagnozy procesu przygotowania i realizacji studiów podyplomowych, powiązanie stosowanych rozwiązań z uzyskiwanymi efektami, co stworzy w konsekwencji podstawy do formułowania wniosków o charakterze normatywnym. W ramach dyskusji nad poszczególnymi modelami realizacji uniwersyteckiego kształcenia ustawicznego, ich cechami i skutecznością warto podzielić się doświadczeniami Uniwersytetu Ekonomicznego we Wrocławiu w tym zakresie.

ograniczonej konkurencji, lecz wraz z rozwojem studiów podyplomowych i krótkich form dydaktycznych, oferowanych przez uczelnie niepubliczne oraz firmy szkoleniowe (duża liczba studiów i szkoleń finansowanych ze środków unijnych), stosowane rozwiązanie przestało odpowiadać potrzebom, co zrodziło potrzebę jego zmiany. W 2010 roku rozpoczęto działania w kierunku zmiany stosowanego rozwiązania $-z$ bardzo zbliżonego do modelu rozproszonego na rozwiązanie zbliżone do modelu scentralizowanego. $W$ ramach sygnalizowanych zmian podjęto $m$.in. decyzję o budowie nowego obiektu na potrzeby studiów podyplomowych oraz powołano pełnomocnika rektora ds. studiów podyplomowych, którego zadaniem było ujednolicanie i koordynacja działań w zakresie studiów podyplomowych, analiza potrzeb i rozwój oferty, a także integracja działań marketingowych.

W 2011 roku rozpoczęto proces ujednolicania procedur i dokumentacji dotyczącej studiów podyplomowych (wcześniej każdy wydział stosował odrębne zasady, własne niepisane procedury i odmienną dokumentację), wdrożono wspólną platformę internetową do obsługi studiów podyplomowych z wieloma funkcjonalnościami (m.in. zapisy elektroniczne, generowanie dokumentów i raportów, komunikacja mailowa ze słuchaczami, monitoring wpłat na konta indywidualne słuchaczy, ewaluacja studiów itd.), a także rozpoczęto działania promocyjne wspólne dla wszystkich studiów podyplomowych. Z uwagi na dużą inercję rozwiązań organizacyjnych, obawy pracowników i wynikające z nich opory, proces zmian przeprowadzany był ewolucyjnie, przy odpowiedniej komunikacji i konsultacjach.

W 2013 roku w nowo wybudowanym obiekcie rozpoczęła działalność międzywydziałowa jednostka Centrum Kształcenia Ustawicznego, przejmując organizację studiów podyplomowych i szkoleń oferowanych przez wszystkie wydziały Uczelni. Scentralizowana została obsługa administracyjna, co pozwoliło na jej pełną standaryzację oraz poprawę dostępności dla słuchaczy (biuro czynne w weekendy, dyżury popołudniowe itd.).

Wypracowany model w pewnym stopniu zbliżył się w swoich założeniach do modelu scentralizowanego. Jednocześnie w kwestiach merytorycznych (programowych i obsady) pozostawiono wydziałom dużą autonomię. Kierownikom studiów i opiekunom merytorycznym dano znaczną swobodę w przygotowywaniu programów i efektów kształcenia, opiniowanych przez odpowiednie rady wydziałów, doborze kadry i formy prowadzonych zajęć. 
Zwiększono również elastyczność w kwestiach finansowych, pozostawiając kierownikom studiów możliwość kształtowania polityki wynagrodzeń i innych kosztów (oczywiście przy zachowaniu warunku bilansowania się każdej edycji studiów). Z uwagi na połączenie cech modeli scentralizowanego i rozproszonego zastosowane na UE we Wrocławiu rozwiązanie można nazwać modelem hybrydowym (Lichtarski i Niemczyk 2015). Rozwiązanie to nie jest oczywiście pozbawione wad, jednak dane dotyczące liczby słuchaczy w latach 2013-2016 potwierdzają jego skuteczność. Warto podkreślić, że inne badane uczelnie ekonomiczne w analogicznym okresie odnotowały spadek liczby słuchaczy na studiach podyplomowych, głównie w obszarze rachunkowości w związku z tzw. uwolnieniem zawodów.

Liczba słuchaczy studiów podyplomowych na UE we Wrocławiu na podstawie dokumentacji Uczelni:

$\begin{array}{lccc}\text { Rok akademicki } & 2013 / 2014 & 2014 / 2015 & 2015 / 2016 \\ \text { Liczba słuchaczy } & 1545 & 1775 & 2089\end{array}$

Wysoki poziom autonomii programowej powoduje powstawanie wewnętrznej konkurencji, co w efekcie prowadzi do powstawania koopetycji, gdyż między poszczególnymi studiami występują również relacje współpracy. Strategie koopetycji określane są jako skuteczne w dobie dynamicznych zmian (Dagnino i Padula 2002; Yami i in. 2010). Kilkuletnie doświadczenie UE we Wrocławiu pozwala stwierdzić, że - mimo potencjalnych zagrożeń związanych z rywalizacją wewnętrzną, z zachowaniem odpowiednich zasad (np. konkurowania jakością oferty, a nie ceną) i woli współpracy między jednostkami - model ten jest skuteczny. Sprzyja bowiem ciągłemu rozwojowi oferty (benchmarking wewnętrzny, ciągłe doskonalenie), dzięki czemu rośnie jej atrakcyjność wobec oferty podmiotów konkurencyjnych.

W nawiązaniu do przedstawionego podejścia analitycznego i po przeprowadzeniu badań z wykorzystaniem analizy studiów przypadku (multi case study) można sformułować dwie następujące hipotezy badawcze:

H1: Im niższy jest poziom centralizacji decyzji i działań w obszarze merytorycznym (programu i obsady) oraz finansowym, tym większa jest skuteczność modelu organizacji kształcenia ustawicznego w dłuższym okresie.

H2: Im wyższy jest poziom centralizacji decyzji i działań w obszarze administracyjnym, tym większa jest skuteczność modelu organizacji kształcenia ustawicznego w dłuższym okresie.

Zamiarem autorów w kolejnych przedsięwzięciach badawczych jest opracowanie metod pomiaru poziomu centralizacji decyzji i działań w wyróżnionych obszarach, a następnie poszukiwanie związków pomiędzy natężeniem centralizacji a efektami na podstawie danych zgromadzonych w ramach reprezentatywnej próby badawczej.

\section{PODSUMOWANIE}

Obserwowane i prognozowane tendencje w otoczeniu społeczno-ekonomicznym polskich uczelni wskazują, że udział i rola tej grupy podmiotów w przygotowywaniu i organizacji procesów kształcenia ustawicznego będą w najbliższych kilku latach coraz większe, podobnie jak ma to miejsce w wysoko rozwiniętych krajach europejskich (Marciszewska i Zbierzchowska 2006). 
Rosnące potrzeby społeczeństwa i rynku pracy w zakresie całożyciowego uczenia się stanowią duże wyzwanie dla uczelni jako inicjatorów i organizatorów m.in. takich form kształcenia ustawicznego, jak studia podyplomowe. Konieczne jest wdrożenie takiego rozwiązania, które pozwoli na szybkie reagowanie, a nawet wyprzedzanie identyfikowanych zmian, dzięki czemu możliwe będzie spełnienie potrzeb i oczekiwań w zakresie kształcenia ustawicznego.

Analityczne spojrzenie na sposób organizacji kształcenia ustawicznego na uczelni, zaprezentowane w niniejszym artykule, jest wstępem do kolejnych badań i zaproszeniem do dyskusji na temat skuteczności stosowanych modeli i rozwiązań w obszarze działań edukacyjnych i rozwojowych polskich uczelni. Wykorzystanie proponowanego podejścia do analizy większej liczby przypadków (w celu zapewnienia reprezentatywności) w zestawieniu $z$ danymi charakteryzującymi skuteczność stosowanych rozwiązań (takimi jak: zakres oferty, liczba słuchaczy, przychody, wyniki badań ewaluacyjnych) pozwoli na weryfikację sformułowanych hipotez badawczych $(\mathrm{H} 1, \mathrm{H} 2)$, a także na wyprowadzenie wniosków o charakterze aplikacyjnym dla krajowych podmiotów szkolnictwa wyższego. Ze względu na zakres i charakter danych niezbędnych do analizy jest pożądane zaproszenie do współpracy i dyskusji przedstawicieli wielu uczelni, co jest również jednym z celów niniejszego opracowania.

Autorzy mają świadomość, że wypracowanie i wdrożenie skutecznego systemu organizacji studiów podyplomowych na uczelni jest utrudnione przez wiele czynników (lub szerzej: uwarunkowań) o charakterze zarówno zewnętrznym (takich jak niestabilność w obszarze regulacji prawnych dotyczących szkolnictwa wyższego, brak stabilności ekonomicznej przedsiębiorstw i gospodarstw domowych) oraz uwarunkowań lokalnych, jak i czynników o charakterze wewnętrznym (takich jak duża inercja dotychczas stosowanych rozwiązań i silne opory przeciwko zmianom, konieczność dostosowania rozwiązania do specyfiki jednostki, m.in. liczby, wielkości i zróżnicowania wydziałów, posiadanych zasobów infrastrukturalnych, potencjału kadrowego).

\section{PIŚMIENICTWO}

Benbasat L., Goldstein D.K., Mead, M. 1987. The case research strategy in studies of information systems. MIS Quarterly 11(3), 369-386.

Budzyńska M. Koncepcja kształcenia ustawicznego w Unii Europejskiej jako jeden ze sposobów realizacji Strategii Lizbońskiej, ze szczególnym uwzględnieniem Polski, http://www.lifelong-learning.pl/unia/9.pdf, dostęp: 27.07.2017.

Clark B. 2004. Sustaining change in universities. Maidenhead, Open University Press.

Coopetition. Winning Strategies for the 21st Century. 2010. Red. S. Yami, S. Castaldo, G.B. Dagnino, F. Le Roy. Cheltenham, Edward Elgar Publishing.

Dagnino G.B., Padula G. 2002. Coopetition strategy. A new kind of interfirm dynamics for value creation, in: Innovative research in management. Papers of the Second Annual Conference, Stockholm, May 9-11, 2002. [b.w.].

Dave R.H. 1976. Foundations of lifelong education. Hamburg, UNESCO Institute for Education.

Delors J. 1996. Learning: The treasure within. Paris, UNESCO Publishing.

Edukacja - jest w niej ukryty skarb. Raport dla UNESCO Międzynarodowej Komisji do spraw Edukacji dla XXI wieku. 1998. Red. J. Delors. Warszawa, Stow. Oświat. Pol.

Field J. 2006. Lifelong learning and the new educational order. Stock on Trent. Trentham Book. 
Groenwald M. 2004. Edukacja przez całe życie - od idei do praktycznych rozwiązań, w: Edukacja ustawiczna w szkołach wyższych - od idei do praktyki. Płock, Wydaw ITE.

Illeris K. 2006. Trzy wymiary uczenia się. Wrocław, Wydaw. DSW.

Kidd R.J. 1983. Lifelong education and international relations. London, Croom Helm.

Kształcenie ustawiczne w Polsce na tle innych krajów - na podstawie badania TRAL, http://www.mpips.gov.pl/praca/programy/badanie-oecd-8222uczenie-sie-doroslych8221-8211-przegladtematyczny/, dostęp: 05.11.2016.

Lichtarski J.M., Niemczyk J. 2015. Organizacja kształcenia ustawicznego w uczelniach wyższych modele i doświadczenia praktyczne, w: Uniwersytet w perspektywie kształcenia przez całe życie. Katowice, Wydaw. UE.

Marciszewska E., Zbierzchowska A. 2006. Kształcenie ustawiczne w europejskich uniwersytetach. Projekty EQUIPE i EQUIPE PLUS. E-mentor 4(16), 43-48.

Międzyresortowy Zespół ds. Uczenia się przez całe życie, w tym Krajowych Ram Kwalifikacji, 2011. Perspektywa uczenia się przez całe życie, https://bip.men.gov.pl/dzialalnosc/c36-programyprojekty/perspektywa-uczenia-si-przez-cae-ycie-dokument-strategiczny, dostęp: 05.11.2016.

Półturzycki J. 1993. Przemiany i perspektywy edukacji dorosłych. Eduk. Dor. 1, 15-24.

Półturzycki J. 2004. Szkolnictwo wyższe a idea edukacji ustawicznej, w: Edukacja ustawiczna w szkołach wyższych - od idei do praktyki. Płock, Wydaw. Inst. Technol. Ekspl.

Sułkowski Ł., Seliga R. 2016. Przedsiębiorczy uniwersytet - zastosowanie zarządzania strategicznego. Pr. Nauk. UE Wroc. 444, 478-489.

Symela K. 1997. Zasady wdrażania i oceny modułowych programów szkoleniowych dorosłych. Warszawa, MPiPS.

Wiśniewski Z. 2006. Kształcenie ustawiczne - centralnie czy niezależnie? E-mentor 4, 57-60.

Yin R.K. 1984. Case study research: design and methods. University Michigan, Sage Publications. 